\title{
CROWDSOURCING W SEKTORZE PUBLICZNYM - WYZWANIE BADAWCZE
}

\begin{abstract}
Crowdsourcing w ujęciu ogólnym oznacza proces pozyskiwania wiedzy, pomysłów, inspiracji z thumu. Narzędziem pomocniczym i swoistym medium jest tutaj Internet. W praktyce gospodarczej stał się mega trendem, który napędza innowacje, współpracę w dziedzinie badań naukowych, biznesu czy społeczeństwa. Sięga po niego coraz więcej organizacji, chociażby z uwagi na potencjalną wartość biznesową. Dostrzega się powiązanie crowdsourcingu $\mathrm{z}$ budowaniem przewagi konkurencyjnej, doskonaleniem procesów biznesowych, optymalizacją kosztów działalności organizacji czy modeli biznesowych. Pojęcia to wzbudza coraz większe zainteresowanie wśród badaczy. Jednakże, zgodnie z opinią wielu autorów, większość publikacji zorientowanych jest na jego wykorzystanie w organizacjach komercyjnych. W sposób niewystarczający zjawisko toanalizowane jest $\mathrm{z}$ punktu widzenia organizacji publicznych. Podkreśla się przy tym, że crowdsourcing $\mathrm{w}$ organizacjach publicznych jest aktualnym kierunkiem badań. Bowiem crowdsourcing postrzegany jest jako połączenie współpracy, agregacji, pracy zespołowej, konsensusu oraz kreatywności. Co ważne, organizacje publiczne zaczynają sięgać po tego typu rozwiązania. W artykule przybliżono ideę crowdsourcingu, dalej przedstawiono przegląd dotychczasowych badań dotyczących crowdsourcinguw organizacjach publicznych oraz nakreślono możliwe kierunki dalszychbadań. Głównym celem niniejszego artykułu jest przedstawienie dotychczasowegodorobku teoretycznego oraz empirycznego nad crowdsourcingiem w organizacjach publicznych ze wskazaniem aktualnych wyzwań badawczych w tymobszarze. Dla realizacji tak skonstruowanego celu wykorzystano metodykę systematycznego przeglądu literatury. $\mathrm{Na}$ tej podstawie zaproponowano następujące wyzwania badawcze: ujednolicenie i uszczegółowienie konceptualizacji pojęcia, prowadzenie badań wielowymiarowych i holistycznych z uwzględnieniem roli pracownika i thumu, wypracowanie sposobów pomiaru oraz ram koncepcyjnych warunków organizacyjnych.
\end{abstract}

Slowa kluczowe: crowdsourcing, organizacje publiczne, sektor publiczny, systematyczny przegląd literatury, konceptualizacja.

\section{WPROWADZENIE}

Rosnące oczekiwania obywateli, wyzwania społeczne, ekonomiczne czy środowiskowe, konieczność transparentności, odpowiedzialności i wydajności organizacji publicznych ${ }^{2}$ czy orientacji usługowej administracji - stają się istotnymi problemami dla organizacji publicznych $^{3}$. Tendencje te są konsekwencjami demokratyzacji życia publicznego oraz chęci

1 Dr Regina Lenart-Gansiniec, Instytut Spraw Publicznych, Uniwersytet Jagielloński, ul. Łojasiewicza 4, 30-348 Kraków, e-mail: regina.lenart-gansiniec@uj.edu.pl.

${ }^{2}$ M. Holzer, K. Kloby, Public performance measurement. An assessment of the state ofthe-art and models for citizen participation, "International Journal of Productivity and Performance Management" 2005, 54(7).

${ }^{3}$ D. Albury, Fostering innovation in public services, "Public Money and Management" 2005, 25; M. Asgarkhani, The effectiveness of e-Service in the Public Sector: A Local Government Perspective, Proceedings of the European Conference on Electronic Government, 2005; S. Borins, 
uczestnictwa obywateli w podejmowaniu decyzji ${ }^{4}$. Dodatkowo wspomina się o konieczności traktowania obywateli jako klientów ${ }^{5}$, co stanowi jeden z kluczowych elementów w procesie postępujących reform administracji publicznej ${ }^{6}$.

W odpowiedzi na nowe wyzwania, w ciągu ostatnich lat $\mathrm{w}$ centrum zainteresowania zarządzania publicznego znajdują się kwestie współuczestnictwa obywateli w procesie sprawowania władzy, podejmowania decyzji, współdecydowania, współzarządzania, współdziałania na rzecz realizacji zadań publicznych ${ }^{7}$ - sugeruje się, aby obywatele i organizacje publiczne wspólnie definiowali problemy i szukali rozwiązań oraz realizowali zadania publiczne.Kluczowe w tym jest angażowanie wszystkich interesariuszy do ciągłego tworzenia nowych produktów, usprawniania i doskonalenia procesów czy tworzenia nowych rozwiązań. Coraz cześsciej podkreśla się znaczenie takich zagadnień, jak: „Collaborative Public Management”, „Citizen Engagement", „Wiki Government" z sektora publicznego ${ }^{11}$ czy „Open Government" ${ }^{\prime 12}$. Podkreśla się tu znaczenie budowania relacji. W literaturze wskazuje się, że są one wyznacznikiem efektywnego funkcjonowania $\operatorname{organizacji~}^{13}$. Takie relacje nie tylko umożliwiają dostęp do nieograniczonych, unikatowych zasobów $^{14}$, ale także mają wpływ na rozwój organizacji ${ }^{15}$ oraz zwiększenie poziomu innowacyjności organizacyjnej ${ }^{16}$. Nie bez znaczenia jest stały dostęp do zasobów wiedzy oraz

The Challenge of Innovating in Government, PricewaterhouseCoopers Endowment for the Business of Government, VA, Arlington 2001.

${ }^{4}$ S. Bowler, T.A. Donovan, Demanding Choices: Opinion, Voting, and Direct Democracy, University of Michigan Press, AnnArbor 2000.

${ }^{5}$ P. Dunleavy, Ch. Hood, From old public administration to new public management, "Public Money \& Management" 1994, 14(3); Ch. Pollitt, G. Bouckaert, Public Management Reform: A Comparative Analysis, Oxford University Press, Oxford 2004.

${ }^{6}$ D. Hilgers, Ch. Ihl, Citizensourcing - Applying the Concept of Open Innovation to the Public Sector, "International Journal of Public Participation" 2010, 4(1).

${ }^{7}$ R. Lister, Citizen in Action: Citizenship and community development in Northern Ireland Context, "Community Development Journal" 1998, 33(3).

${ }^{8}$ M. McGuire, Collaborative Public Management: Assessing What We Know and How We Know It,"Public Administration Review" 2006, 66(1).

${ }^{9}$ M. Hickley, The Grounds for Citizen Engagement and the Roles of Planners, Saarbruecken: VDM, 2008; OECD. Promise and Problems of E-Democracy: Challenges of Online Citizen Engagement, OECD Publications, Paris 2004.

${ }^{10}$ B. S. Noveck, Wiki Government: How Technology Can Make Government Better, Democracy Stronger, and Citizens More Powerful, Brookings Institution Press, Washington, D.C 2009.

11 J. Alford, Engaging public sector clients: from service delivery to co-production, Palgrave Macmillan, Basingstoke 2009.

${ }^{12}$ OECD. Open government legislation, OECD Publishing, Paris 2009.

${ }^{13}$ W. Czakon, Dynamika więzi międzyorganizacyjnych przedsiębiorstwa, Wydawnictwo Akademii Ekonomicznej w Katowicach, Katowice 2007.

${ }^{14}$ J.K. Ford, E. M. Smith, D.A. Weissbein, S.M. Gully, E. Salas, Relationships of goal orientation, metacognitive activity, and practice strategies with learning outcomes and transfer, "Journal of Applied Psychology"1998, 83(2).

${ }^{15}$ L. Edvinsson, M. S. Malone, Kapitat intelektualny, Wydawnictwo PWN, Warszawa 2011.

${ }^{16}$ W. Powell, K. Koput, L. Smith-Doerr, Interorganizational Collaboration and the Locus of Innovation: Networks of Learning in Biotechnology, "Administrative Science Quarterly"1996, 41 (1). 
konieczność jej aktualizowania ${ }^{17}$. Co więcej, to właśnie relacje pozwalają organizacji na stały dostęp do wiedzy czy pomysłów znajdujących się poza nią. Literatura podkreśla, że redundancja zasobów generuje $\mathrm{i}$ absorbuje informacje. W tym przypadku nadmiar i różnorodność wiedzy jest źródłem tworzenia nowych produktów ${ }^{18}$. A zatem, nadmiar wiedzy, nawiązywanie relacji - sprzyjają tworzeniu wiedzy. W takim ujęciu, nowa wiedza, pomysły wyłaniają się z nadmiaru i chaosu ${ }^{19}$.

$\mathrm{W}$ poszukiwaniu rozwiązań czy sposobów radzenia sobie z rosnącymi wymaganiami i oczekiwaniami obywateli, koniecznością otwartości na głosy płynące $\mathrm{z}$ otoczenia, dostępu do wiedzy - coraz częściej wskazuje się na otwarte innowacje. W szczególności w obszarze zainteresowania organizacji - także publicznych - jest crowdsourcing. Uznawany jest on za model do rozwiązywania problemów, zarządzania partycypacyjnego, zwiększenia przejrzystości i otwartości organizacji publicznych. Odnosi się on do procesu pozyskiwania wiedzy, pomysłów, inspiracji z tłumu ${ }^{20}$. Jest on uznawany za swegorodzaju uczestniczącą aktywność on-line, w którym dana osoba, instytucja, organizacja non-profit, czy firma wysyła do różnych osób, zazwyczaj społeczności wirtualnych, zaproszenie do poszukiwania rozwiązań danego zadania czy problemu ${ }^{21}$. Proces pociąga za sobą szereg nowych problemów, pojęć i decyzji menedżerskich, ale także oferuje duże korzyści dotyczące tworzenia nowych produktów i usług, a także aktywuje innowacje.

Głównym celem niniejszego opracowania jest przedstawienie dotychczasowego dorobku teoretycznego oraz empirycznego nad crowdsourcingiem w organizacjach publicznych ze wskazaniem aktualnych wyzwań badawczych $w$ tym obszarze. Dla realizacji tak skonstruowanego celu wykorzystano metodykę systematycznego przeglądu literatury. Prowadzone dotychczas badania koncentrują się głównie na wykorzystaniu crowdsourcingu w organizacjach komercyjnych ${ }^{22}$, a szczegółowiej w kontekście otwartej innowacji ${ }^{23}$, innowacji ${ }^{24}$, rozwiązywania problemów on-line ${ }^{25}$, kultury uczestniczącej ${ }^{26}$.

${ }^{17}$ B. Mikuła, Organizacje oparte na wiedzy, Wydawnictwo Akademii Ekonomicznej w Krakowie, Kraków 2006.

18 A. Stabryła, S. Wawak (red.), Problemy zarządzania organizacjami w spoleczeństwie informacyjnym, Wydawnictwo Mfiles.pl, Kraków 2014.

${ }_{19}$ R.D. Stacey, Strategic Management and Organizational Dynamics,Pitman,London 1993; M. Wheatley, Leadership and the New Science: Discovering Order in a Chaotic World, BerrettKoehler Publishers 1994.

${ }^{20}$ J. Howe, Crowdsourcing: Why the Power of the Crowd Is Driving the Future of Business, Crown Publishing Group, New York 2008.

${ }^{21}$ D.C. Brabham, Crowdsourcing as a Model for Problem Solving: An Introduction and Cases', Convergence, "The International Journal of Research into New Media Technologies" 2008, 14(1); M. Lodge, K. Wegrich, Crowdsourcing and Regulatory Reviews: A New Way of Challenging Red Tape in British Government?, "Regulation\&Governance" 2015, 9(1).

22 J. Albors, J.C. Ramos, J.L., Hervas, New learning network paradigms: Communities of objectives, crowdsourcing, wikis and open source, "International Journal of Information Management" 2008, 28; A. Kittur, E.H. Chi, B. Suh, Crowdsourcing for Usability: Using MicroTask Markets for Rapid, Remote, and Low-cost User Measurements, Proceedings of CHI, 2008.

${ }^{23}$ H. W. Chesbrough, Open Innovation: The New Imperative for Creating and Profiting from Technology, Boston: Harvard Business School Press, Boston 2003.

${ }^{24}$ E. Von Hippel, Democratizing Innovation, MIT Press Cambridge, Massachusetts 2005.

${ }^{25}$ L.B. Jeppesen, K.R. Lakhani, Marginality and problem solving effectiveness in broadcast search, "Organization Science" 2010, 21(5). 
Według danych Google Scholar istnieje 57600 artykułów teoretycznych i empirycznych poświęconych crowdsourcingowi, lecz 19200 ujmujących crowdsourcing w organizacji publicznej. Większość z tych publikacji obejmuje obszar psychologii i informatyki. W opinii autorki nadal brakuje badań prowadzonych z punktu widzenia zastosowania crowdsourcingu w organizacjach publicznych.Co ważne, dotychczasowa aktywność „crowdsourdingowa” organizacji publicznych w Polsce pozwala na stwierdzenie, że może on generować duże zainteresowanie wśród obywateli i służyć jako źródło nowych innowacji (platforma Otwarta Warszawa: 16600 zarejestrowanych użytkowników, 1147 pomysłów przekazanych przez tłum, wdrożono 24 pomysły). Niedobór badań empirycznych w tym zakresie stanowi podstawę podjęcia tego tematu.

Praca składa się $\mathrm{z}$ trzech części. Część pierwsza przedstawia istotę i pojęcie crowdsourcingu $\mathrm{z}$ punktu widzenia nauk o zarządzaniu. W części drugiej ujęto wyniki systematycznego przeglądu literatury. Możliwe kierunki dalszych badań w zakresie crowdsourcingu w sektorze publicznym ujęto w części ostatniej, trzeciej. Zawarto tutaj także implikacje dla teorii oraz praktyki zarządzania.

\section{ISTOTA I POJECIE CROWDSOURCINGU}

Termin crowdsourcingu po raz pierwszy został użyty na początku 2006 roku przez dziennikarzy J. Howe’a i M. Robinsona. Ich definicja odnosi się do systemów sieciowych i dotyczy nowego,opartego na Internecie modelu biznesowego, w którym wykorzystuje się do kreowania twórczych rozwiązań sieć rozproszonych osób. Jest to zatem działanie organizacji, które polega na wydzieleniu funkcji i ich outsourcing do bliżej niezdefiniowanej dużej grupy osób, w formie otwartego zaproszenia ${ }^{27}$. Ten swoistego rodzaju neologizm stanowi kontaminację następujących pojęć: outsourcing, thum, społecznościowe serwisy internetowe ${ }^{28}$. A zatem, podstawowym budulcem jest tłum, który uznawany jest za eksperta ${ }^{29}$.

Istnieje w literaturze stosunkowo duża prób zdefiniowania crowdsourcingu. Należy jednak podkreślić, że pomimo mnogości definicji nadal obserwuje się brak konsensusu oraz semantyczne zamieszanie. Crowdsourcing analizowany w oparciu o różne ramy koncepcyjne: (1) podstawowe funkcje, korzyści, problemy, (2) motywowanie lub niemotywowanie tłumu ${ }^{30}$, (3) anonimowość ${ }^{31}$ lub jawność członków społeczności wirtualnej ${ }^{32}$ (tabela 1).

\footnotetext{
${ }^{26}$ H. Jenkins, R. Purushotma, K. Clinton, M. Weigel, A. J. Robison, Confronting the Challenges of Participatory Culture: Media Education for the 21st Century, The MacArthur Foundation, Chicago 2006.

${ }^{27}$ J. Howe, The rise of crowdsourcing, "Wired Magazine" 2006, 14(6).

28 P. Whitla, Crowdsourcing and its Application in Marketing Activities, "Contemporary Management Research" 2009, 5(1).

${ }^{29}$ L. B. Jeppesen, K. R. Lakhani, Marginality and problem solving effectiveness in broadcast eearch, "Organization Science" 2010, 21(5); J. M. Leimeister, Collective intelligence, "Business and Information Systems Engineering" 2010, 4(2).

${ }^{30}$ A. J. Quinn, B.B. Bederson, Human computation: a survey and taxonomy of a growing field, Proceedings of the SIGCHI Conference on Human Factors in Computing Systems, 2011; D. C. Brabham, Crowdsourcing the Public Participation Process for Planning Projects, "Planning Theory"2009, 8(3); P. Fraternali, A. Castelletti, R. Soncini-Sessa, V.C. Ruiz, A. E. Rizzoli, Putting humans in the loop: Social computing for Water Resources Management, "Environmental Modelling \& Software"2012, 37; O. Alonso, M. Lease, Crowdsourcing for information retrieval: Principles, methods, and applications, Tutorial at the 34th annual ACM SIGIR conference, 2011; V. Chanal, M.L. Caron-Fasan, How to invent a new business model based on crowdsourcing: The crowdspirit $R$
} 
Tabela 1. Definicje crowdsourcingu

\begin{tabular}{|c|c|}
\hline Ramy koncepcyjne & $\begin{array}{l}\text { Definicje } \\
\end{array}$ \\
\hline Outsourcing & $\begin{array}{l}\text { outsourcing zadań do dużej grupy osób, zamiast przypisywania } \\
\text { takich zadań pracownikom [Alonso, Lease, 2011], akt spółki lub } \\
\text { instytucji, który polega na outsourcingu zadań dotychczas } \\
\text { wykonywanych przez pracowników do nieokreślonej (i ogólnego } \\
\text { dużej) sieci osób w formie otwartej rozmowy [Howe, 2006], } \\
\text { outsourcing zadania do dużej grupy potencjalnych innowatorów } \\
\text { [Liu, Porter, 2010], wykorzystanie outsourcingu do przekazywania } \\
\text { zadań tlumowi, tworzenie aktywów intelektualnych, dostęp do } \\
\text { szerokiej gamy umiejętności i doświadczenia [Oliveira et al., 2010], } \\
\text { outsourcing generowania pomysłów do potencjalnie dużychi } \\
\text { nieznanych populacji w formie otwartego zaproszenia [Poetz, } \\
\text { Schreier, 2009], akt outsourcingu, w formie zaproszenia } \\
\text { otwartego, skierowany do dużej grupie osób spoza organizacji } \\
\text { [Sloane, 2011] }\end{array}$ \\
\hline Społeczności wirtualne & $\begin{array}{l}\text { spoleczności on-line, które rozwiązują problemy [Brabham, 2008], } \\
\text { model strategiczny, którego zadaniem jest przyciągnięcie z tlumu } \\
\text { zainteresowanych, zmotywowanych, zdolnych osób do } \\
\text { dostarczania najwyższej jakości rozwiązań [Brabham, 2008], } \\
\text { szczególny przypadek zbiorowej inteligencji [Buecheler et al., } \\
\text { 2010], zestaw metod zachęcania społeczności wirtualnych do } \\
\text { poszukiwania rozwiązań zadań poprzez otwarte zaproszenie na dużąa } \\
\text { skalę [DiPalantino, Vojnovic, 2009], stosunkowo nowe zjawisko, w } \\
\text { którym pracownicy web w sposób kompletny wykonują zadania, } \\
\text { często dla mikropłatności, rzędu od 0,01 do 0,10 dolarów za zadanie } \\
\text { [Heer, Bostok, 2010], uzyskanie jednego lub więcej użytkowników } \\
\text { Internetu do zdalnego wykonywania prac [Heymann, Garcia- } \\
\text { Molina, 2011], poznanie klientów bezpośrednio i sięganie po ich } \\
\text { pomoc w każdym aspekcie cyklu produktu lub usługi [Porta et al., } \\
\text { 2008], wykorzystanie społeczności internetowej do wykonania } \\
\text { zadań [Yang et al., 2009], proces organizowania pracy i przekazanie } \\
\text { jej do spoleczności internetowej [Whitla, 2009] }\end{array}$ \\
\hline Wiedza & $\begin{array}{l}\text { sposób dostępu do wiedzy zewnętrznej [Burger-Helmchen, Penin, } \\
\text { 2010], mechanizm, dzięki któremu talent i wiedza tlumu jest } \\
\text { dopasowana do potrzebujących organizacji [Howe, 2008], celowa } \\
\text { mobilizacja komercyjnego wykorzystania kreatywnych pomysłówi } \\
\text { innych form pracy wykonywanej przez konsumenta [Kleeman et } \\
\text { al., 2008], zastosowanie wiedzy pochodzącej z tlumu do } \\
\text { rozwiązywania problemów [Wexler, 2011] }\end{array}$ \\
\hline Innowacje & otwarcieprocesu innowacyjnego, integrowanie, rozpowszechniane \\
\hline
\end{tabular}

case, EURAM Conference, 2008; D. DiPalantino, M. Vojnović, Crowdsourcing and all-pay auctions, Proceedings of the 10th ACM conference on Electronic commerce 2009.

${ }^{31}$ M. Hirth, T. Hoßfeld, P. Tran-Gia, Anatomy of a crowdsourcing platform-using the example of microworkers.com, Innovative Mobile and Internet Services in Ubiquitous Computing (IMIS), Fifth International Conference on, 2011.

${ }^{32}$ P. Fraternali, A. Castelletti, R. Soncini-Sessa, V.C. Ruiz, A.E. Rizzoli, Putting humans in the loop: Social computing for Water Resources Management,"Environmental Modelling \& Software"2012, 37. 


\begin{tabular}{|c|c|}
\hline & $\begin{array}{l}\text { zewnętrznych kompetencje przy wykorzystaniu platform } \\
\text { internetowych [Chanal, Caron-Fasan, 2008], model e-biznesu, } \\
\text { w którym za pośrednictwem otwartego zaproszenia, pozyskuje się } \\
\text { innowacyjne rozwiązania [Howe, 2008], nowy model biznesowy } \\
\text { innowacji poprzez internet [Ling, 2010], przejaw otwartej } \\
\text { innowacji [Sloane, 2011] }\end{array}$ \\
\hline Problemy & $\begin{array}{l}\text { ogólnego przeznaczenia metoda rozwiązywania problemów [Doan } \\
\text { et al., 2011], otwarte zaproszenie do thumu oraz zlecanie zadań i } \\
\text { problemów do rozwiązania [Kazai, 2011], narzędzie do } \\
\text { rozwiązywania problemów w organizacji i działalności [La } \\
\text { Vecchia, Cisternino, 2010], celowe mobilizacja poprzez web 2.0, } \\
\text { tłumu do tworzenia kreatywnych i innowacyjnych pomysłów lub } \\
\text { rozwiązywania problemów [Mazzola, Distefano, 2010], otwarte } \\
\text { zaproszenie członków on-line do tworzenia twórczych pomysłów, } \\
\text { rozwiązania problemu, oceny problemów biznesowych [Ribiere, } \\
\text { Tuggle, 2010], rozwiązywanie problemów i tworzenie nowych } \\
\text { produktów przy pomocy osób z sieci on-line [Vukovic, 2009], nowy } \\
\text { model kreowania, w którym ludzie wspólpracują i poszukują } \\
\text { rozwiązań [Vukovic, 2009] }\end{array}$ \\
\hline Internet & $\begin{array}{l}\text { sposób korzystania z Internetu do zatrudniania dużej liczby } \\
\text { rozproszonych pracowników [Grier, 2011], przemysł, który jest } \\
\text { próbą użycia istot ludzkich i maszyn w dużych systemach } \\
\text { produkcyjnych [Grier, 2011], ludzie poświęcają swój czas, aby } \\
\text { zrealizować przez Internet zadania zlecone przez } \\
\text { przedsiębiorstwa [Quinn, Bederson, 2011], }\end{array}$ \\
\hline Otwarte zasoby & $\begin{array}{l}\text { stosowanie zasad open source w dziedzinach poza } \\
\text { oprogramowania [Howe, 2008], oparty na filozofii open source, } \\
\text { w której wykorzystuje się duży thum oraz programistów do } \\
\text { stworzenia systemu operacyjnego Linux [Sloane, 2011] }\end{array}$ \\
\hline Współpraca & $\begin{array}{l}\text { tworzenie wartości interaktywnych, rozwój nowych produktów: } \\
\text { poprzez wspólpracę pomiędzy organizacją a użytkownikiem } \\
\text { [Reichwald, Piller, 2006] }\end{array}$ \\
\hline
\end{tabular}

Źródło: opracowanie własne.

Analiza definicji crowdsourcingu i ich przegląd pozwoliły na wskazanie cech wspólnych: outsourcing, społeczności wirtualne, wiedza, innowacje, problemy, Internet, otwarte zasoby oraz współpraca. Dodatkowo, należy zauważyć, że definicje ujmują znaczenie thumu, jako zbiorowości rozproszonej, ale posiadającą inteligencję oraz motywację i chęć do rozwiązywania problemów. Tym samym można stwierdzić, że crowdsourcing jest swego rodzaju uczestnicząca aktywnością on-line, partycypacją, w której organizacja zaprasza thum do współpracy ${ }^{33}$. Najprościej mówiąc, o crowdsourcingu możemy mówić w sytuacji, gdy: organizacja chce przekazać innym zadanie do wykonania w ręce tłumu, a ten wykonuje je w sposób dobrowolny ${ }^{34}$, natomiast wyniki tej pracy są korzystne dla obydwu stron.

\footnotetext{
${ }^{33}$ J. Prpić, P. Shukla, J.H. Kietzmann, McCarthy I. P., How to Work a Crowd: Developing Crowd Capital through Crowdsourcing, "Business Horizons" 2015, 8(1).

${ }^{34}$ O. Gassmann, Crowdsourcing - Innovationsmanagement mit Schwarmintelligenz, Hanser-Verlag, München 2012
} 
Wykorzystanie w procesie crowdsourcingu outsourcingu oraz thumu pozwala na: (1) budowanie relacji ze społecznościami wirtualnymi ${ }^{35}$, (2) pozyskanie $\mathrm{z}$ ich wiedzy i mądrości ${ }^{36}$ do rozwiązywanie problemów ${ }^{37}$ przy niskich kosztach, (3) pozyskiwanie i tworzenie innowacyjnych rozwiązań różnych problemów ${ }^{38}$, (4) tworzenie otwartych innowacji ${ }^{39}$, (4) budowanie zdolności organizacji do konkurowania ${ }^{40}$. W przypadku thumu - głównymi korzyściami są: satysfakcja, budowanie prestiżu i pozycji w grupie, uznanie społeczne, realizacjach osobistych ambicji, potrzeby samorealizacji, poczucie własnej wartości, uczestnictwo w tworzeniu innowacji, nowych produktów o kreatywnych rozwiązań ${ }^{41}$.

Crowdsourcing może być wykorzystywany w różnorodnych dziedzinach działalności gospodarczej. Daren B. Brabham, kontynuator koncepcji J. Howe'a, wskazuje na cztery wymiary zastosowania: (1) odkrywanie, tworzenie, zarządzanie, gromadzenie wiedzy znajdującej się w różnych źródłach, (2) zlecenie społeczności wirtualnej poszukiwania rozwiązania konkretnego problemu, (3) produkcja partnerska, kreowanie nowych rozwiązań przez społeczność wirtualną, (4) możliwość analizy dużej ilości pozyskanych od ekspertów i amatorów ${ }^{42}$.

Pojęcie crowdsourcingu jest wielowymiarowym ${ }^{43}$. W literaturze wyróżnia się trzy podstawowe wymiary: crowdvoting (dodatkowo crowdtesting), crowdfunding and crowdcreation. Stanowią one swoiste wsparcie dla crowdsourcingu (tab. 2).

\footnotetext{
${ }^{35}$ Y. Yang, Pei-Tu Chen, P. Pavlou, Open Innovation: An Empirical Study of Online Contest, Proceedings of Thirteenth International Conference on Information Systems, Phoenix, 2009.

${ }^{36}$ J. Surowiecki, The Wisdom of Crowds: Why the Many Are Smarter Than the Few and How Collective Wisdom Shapes Business, Economies, Societies, and Nations, Doubleday, New York 2004.

${ }^{37}$ M. Vukovic, Crowdsourcing for enterprises, Proceedings of the 2009 Congress on Services - I, IEEE Computer Society, 2009.

${ }^{38}$ P. Sloane, A Guide to Open Innovation and Crowdsourcing: Advice from Leading Experts, Kogan Page Publishers, UK 2011

39 H. W. Chesbrough, Open Innovation: The New Imperative for Creating and Profiting from Technology, Boston: Harvard Business School Press, Boston 2003.

${ }^{40} \mathrm{Ch}$. Grundström, Ch. Öberg, A. Öhrwall Rönnbäck, View and management of innovativeness upon succession in family-owned SMEs, "International Journal of Innovation Management" 2011, 15(3).

41 E. Estelles-Arolas, F.Gonzalez-Ladron-de-Guevara, Towards an Integrated Crowdsourcing Definition,"Journal of Information Science"2012, 38(2); J.M. Leimeister, S. Zogaj, Neue Arbeitsorganisation durch Crowdsourcing: Eine Literaturstudie, Hans Böckler Stiftung, Düsseldorf 2013.

${ }^{42}$ D.C. Brabham, Crowdsourcing as a Model for Problem Solving: An Introduction and Cases', Convergence, "The International Journal of Research into New Media Technologies" 2008, 14(1).

43 A.C. Rouse, A preliminary taxonomy of crowdsourcing, 21st Australasian Conference on Information Systems, 2010; B. Unterberg, Crowdsourcing, [In:] Social Media Handbuch: Theorien, Methoden, Modelle, D. Michelis, T. Schildhauer, Nomos Verlag, Baden-Baden 2010; Pelzer C., Crowdsourcing Terminologie, 2011, http://www.Crowdsourcingblog.de; J.M. Leimeister, Collective intelligence, "Business and Information Systems Engineering" 2010, 4(2); J.M. Leimeister, S. Zogaj, Neue Arbeitsorganisation durch Crowdsourcing: Eine Literaturstudie, Hans Böckler Stiftung, Düsseldorf 2013.
} 
Tabela 2. Wymiary crowdsourcingu

\begin{tabular}{|c|c|c|c|c|}
\hline Data & Autor/autorzy & Wymiar & Podzial & Charakterystyka \\
\hline 2010 & Unterberg & \multirow[b]{3}{*}{ crowdvoting } & \multirow{3}{*}{$\begin{array}{l}\text { rekomendacja } \\
\text { głosowanie } \\
\text { ewaluacja }\end{array}$} & \multirow{3}{*}{$\begin{array}{l}\text { wezwanie tłumu do } \\
\text { uczestnictwa } \\
\text { w procesie wyboru, oceny, } \\
\text { głosowania } \\
\text { i rekomendacji pomysłów }\end{array}$} \\
\hline 2010 & Leimeister & & & \\
\hline 2013 & Solemon et al. & & & \\
\hline 2010 & Unterberg & \multirow{3}{*}{ crowdfunding } & \multirow{3}{*}{$\begin{array}{l}\text { crowddonating } \\
\text { crowdlending } \\
\text { crowdinvesting } \\
\text { crowdsponsoring }\end{array}$} & \multirow{3}{*}{$\begin{array}{l}\text { możliwość otrzymania } \\
\text { finansowania ze środków } \\
\text { znajdujących się w } \\
\text { posiadaniu tłumu }\end{array}$} \\
\hline 2013 & Harrisson & & & \\
\hline 2013 & Agrawal et al. & & & \\
\hline 2010 & Unterberg & \multirow{4}{*}{ crowdcreation } & \multirow{4}{*}{$\begin{array}{l}\text { opracowanie projektowe } \\
\text { przyjmowaniemikrozadań } \\
\text { generowania pomysłów }\end{array}$} & \multirow{4}{*}{$\begin{array}{l}\text { zintegrowanie thumu } \mathrm{w} \\
\text { procesie opracowywania i } \\
\text { tworzenia otwartej } \\
\text { innowacji }\end{array}$} \\
\hline 2012 & Suciu, Suciu & & & \\
\hline 2010 & Leimeister & & & \\
\hline 2013 & Pedersen et al. & & & \\
\hline
\end{tabular}

Źródło: opracowanie własne.

Podsumowując, pojęcie crowdsourcingu jest złożone i opiera się na mądrości tłumu ${ }^{44}$, wykorzystaniu wiedzy i umiejętności społeczności wirtualnych do tworzenia nowych produktów czy rozwiązywania problemów ${ }^{45}$. Podkreśla się znaczenie kapitału tłumu ${ }^{46}$. Uznajesię, że grupa może osiągnąć i wypracować więcej korzyści niż jakikolwiek ekspert ${ }^{47}$. Dodatkowo istotne są: Internet oraz otwarta współpraca z tumem za pośrednictwem platformy crowdsourcingowej ${ }^{48}$.

\section{METODYKA SYSTEMATYCZNEGO PRZEGLĄDU LITERATURY}

W celu zidentyfikowania obszarów przyszłych badań, wykonano systematyczny przegląd literatury $^{49}$. Jest to obiektywne i syntetyczne narzędzie, które jest podporządkowane selekcji i krytycznej ocenie aktualnych badań ${ }^{50}$. Pozwala także na identyfikację, ocenę i syntezę wyników wszystkich badań podstawowych i podejść teoretycznych, co umożliwia wskazanie

\footnotetext{
${ }^{44}$ J. Surowiecki, The Wisdom of Crowds: Why the Many Are Smarter Than the Few and How Collective Wisdom Shapes Business, Economies, Societies, and Nations, Doubleday, New York 2004.

${ }^{45}$ T. Burger-Helmchen, J. Pénin, The limits of crowdsourcing inventive activities: What do transaction cost theory and the evolutionary theories of the firm teach us?,Workshop on Open Source Innovation, Strasbourg, France 2010.

${ }^{46}$ J. Prpić, P. Shukla, The Theory of Crowd Capital, Proceedings of the Hawaii International Conference on System Sciences \#46, 2012.

${ }^{47}$ L.B. Jeppesen, K.R. Lakhani, Marginality and problem solving effectiveness in broadcast search, "Organization Science" 2010, 21(5); J.M. Leimeister, Collective intelligence, "Business and Information Systems Engineering" 2010, 4(2).

48 J. Prpić, P. Shukla, J.H. Kietzmann, I.P. McCarthy, How to Work a Crowd: Developing Crowd Capital through Crowdsourcing, "Business Horizons" 2015, 8(1).

${ }^{49}$ W. Czakon, Metodyka systematycznego przegladu literatury, „Przegląd Organizacji” 2011, 3.

50 J. Rowley, F. Slack, Conducting a literature review, “Management Research News” 2004, 27(6).
} 
istniejących luk poznawczych i badawczych ${ }^{51}$. Zgodnie z jego metodyką cała procedura obejmuje trzy etapy: (1) wyodrębnienie baz danych oraz zbioru publikacji, (2) selekcja publikacji, opracowanie bazy danych, (3) analiza bibliometryczna, analiza treści oraz weryfikacja przydatności uzyskanych wyników do dalszych badań.

Etap pierwszy systematycznego przeglądu literatury rozpoczął się od zbierania i wyboru literatury. Gromadzenie zbioru publikacji polegało na dokonaniu wyboru baz danych, które $\mathrm{w}$ dalszej kolejności zostaną poddane analizie. W tym celu, wzięto pod uwagę bazy danych, które są największymi i obejmują większość czasopism z zakresu zarządzania strategicznego, tj. Proquest, Elsevier, Emerald, Scopus oraz ISI Web of Science. Wstępną analizę rozpoczęto od przeglądu dostępnych artykułów na stronie http://knowledge.sagepub.com. Jest to pełnotekstowa baza magazynów naukowych wydawnictwa SAGE. Wybrano tę bazę celowo, ze względu na fakt, że jest ona pełnotekstowai wielodziedzinowa oraz gromadzi pełne teksty artykułów z czasopism naukowych z zakresu nauk ekonomicznych. Dodatkowo dokonano przeglądu prezentowanych podczas międzynarodowej konferencji „20th International ResearchSociety on Public Management Conference 2016 Hong Kong (IRSPM)" - której autorka była uczestnikiem. W rezultacie przeszukiwań wybranych baz danych uzyskano ponad 33000 publikacji. Podstawowym kryterium było słowo „,crowdsourcing” w tytule publikacji.

W drugim etapie na zidentyfikowane artykuły nałożono następujące ograniczenia: (1) pelnotekstowe, recenzowane publikacje, (2) „sektor publiczny”, „organizacja publiczna” w tytule, abstrakcie, słowach kluczowych (3) obszar nauk o zarządzaniu. Odrzucono te publikacje, które nie dotyczyły stricte crowdsourcingu, a raczej traktowały go jako temat poboczny. Jako badawczo istotne uznano tylko te publikacje, których wiodącym obiektem analiz był termin crowdsourcing umieszczony $\mathrm{w}$ tytule, słowach kluczowych. Ze zbioru wyłączono publikacje z zakresu informatyki, nauk społecznych, technicznych, matematycznych, humanistycznych, oraz medycznych. Wyeliminowano także publikacje dublujące się, książki, dysertacje oraz rozdziały w książkach. Włączone zostały artykuły recenzowane w pełnej wersji publikowane w czasopismach. Uzyskana w ten sposób baza licząca 30publikacji w kolejnych etapach podlegała dalszej analizie (tab. 3).

W etapie trzecim, zgromadzona baza literaturowa w postaci 30 publikacji została poddana pogłębionej analizie treści. Ten etap będzie stanowił podstawę oceny dotychczas opublikowanych publikacji, identyfikacji luk badawczych i poznawczych, wartościowo poznawczych oraz ważnych dla rozwoju teorii zarządzania obszarów dalszej eksploracji naukowej. Tym samym etap ten stanowi uzasadnienie konieczności podjęcia dalszych badań. Dlatego też rozważania teoretyczne i poprzednie badania empiryczne były oceniane z punktu widzenia jakości, adekwatności oraz perspektyw badawczych.

W ramach metodyki systematycznego przeglądu literatury dokonano analizy liczby publikacji w poszczególnych latach (rys. 1).

\footnotetext{
${ }^{51}$ Y. Levy, T.J. Ellis, A systems approach to conduct an effective literaturereview in support of information systems research, "Informing Science:International Journal of an Emerging Transdiscipline" 2006, 9.
} 
Tabela 3. Proces budowania literatury podstawowej

\begin{tabular}{|c|c|c|c|c|c|}
\hline \multirow{2}{*}{ Kryteria } & \multicolumn{5}{|c|}{ Bazy danych } \\
\hline & Proquest & Elsevier & Emerald & Scopus & $\begin{array}{l}\text { ISI Web } \\
\text { of Science }\end{array}$ \\
\hline „,crowdsourcing” w tytule & 22723 & 4476 & 328 & 4854 & 810 \\
\hline $\begin{array}{l}\text { „organizacja publiczna”, „,sektor publiczny” w } \\
\text { tytule, abstrakcie, słowach kluczowych }\end{array}$ & 1462 & 209 & 39 & 70 & 12 \\
\hline Obszar nauk o zarządzaniu & 17 & 19 & 34 & 30 & 5 \\
\hline Recenzowane artykuły w pełnej wersji & 16 & 16 & 13 & 20 & 5 \\
\hline Po usunięciu publikacji dublujących się & \multicolumn{5}{|c|}{19} \\
\hline Artykuły z Sage & \multicolumn{5}{|c|}{9} \\
\hline Artykuły z IRSPM 2016 & \multicolumn{5}{|c|}{2} \\
\hline $\begin{array}{l}\text { Łącznie: liczba publikacji zakwalifikowana do } \\
\text { analizy treści }\end{array}$ & \multicolumn{5}{|c|}{30} \\
\hline
\end{tabular}

Źródło: opracowanie własne. Stan na dzień: 24.04.2016.

Rys. 1. Liczba publikacji w bazach anglojęzycznych na temat crowdsourcinguw latach 20062016

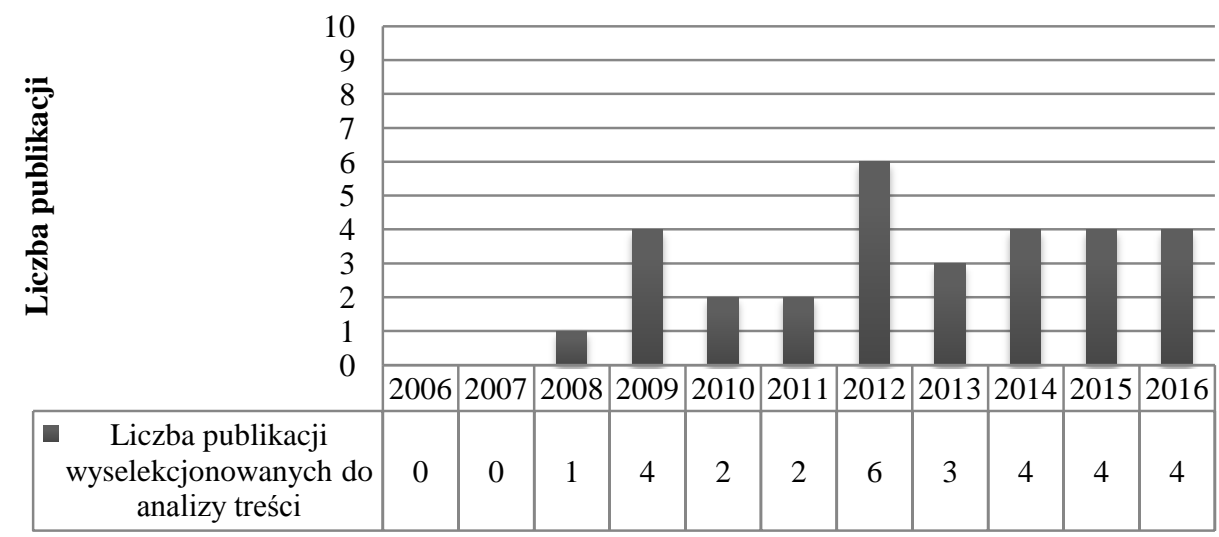

Źródło: Opracowanie własne. Stan na dzień: 24.04.2016.

Analiza liczby publikacji pozwala na stwierdzenie, że zagadnienie crowdsourcingu w kontekście organizacji publicznych cieszy się zainteresowaniem wśród badaczy. Wnioski takie pozwalają na stwierdzenie aktualności rozważań na temat crowdsourcingu $\mathrm{w}$ organizacjach publicznych. Tym samym, pole badawcze staje się coraz bardziej popularne w literaturze naukowej. Pierwsze publikacje w dziedzinie nauk społecznych ukazały się zaledwie siedem lat temu - w 2009 roku. Dodatkowo, liczba trendu publikacji znajdujących się w bazach anglojęzycznych wynosząca $\mathrm{R}^{2}=0,555$ świadczy o tendencji wzrostowej publikacji. Należy 
podkreślić, że liczba publikacji w roku 2014 oraz 2015 była większa niż ta przedstawiona na wykresie. Niektóre publikacje zostały wyłączone ze względu na ograniczony, z powodów licencyjnych, dostęp do wersji pełnotekstowych. Na podstawie powyższego autorka wysuwa wniosek o bieżącym, aczkolwiek młodym, aktualnym obszarze badawczym.

\section{WYNIKI SYSTEMATYCZNEGO PRZEGLĄDU LITERATURY}

\subsection{Analiza frekwencyjności}

Otrzymaną bazę publikacji poddano analizie z wykorzystaniem technik bibliometrycznych. Wykonano zatem analizę frekwencyjności słów kluczowych, stosowanych metod badawczych, podstaw teoretycznych, ośrodków badawczych, problemów badawczych.Wykorzystywane przez autorów w publikacjach słowa kluczowe nie tylko ułatwiają odnalezienie artykułu w bazach danych, ale także odzwierciedlają jego specyfikę. Analizie poddano publikacje wyłonione w ramach trójstopniowej selekcji doboru przedmiotu badań. Wyselekcjonowane i zebrane słowa kluczowe zostały poddane analizie ilościowej, zaś wizualizację frekwencyjności przedstawiono za pomocą „chmury słów”. W graficznej prezentacji słów kluczowych częstotliwość występowania określona jest za pomocą wielkości i pogrubienia czcionki (rysunek 2).

Rys. 2. Chmura słów - analiza frekwencyjności słów kluczowych

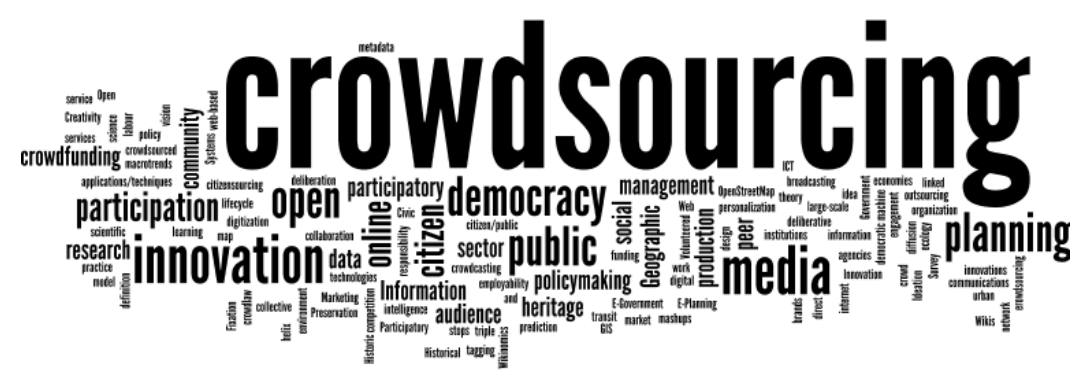

Źródło: Wizualizacja wykonana za pomocą Wordle (http://www.wordle.net).

Należy podkreślić, że sześć na trzydzieści publikacji zakwalifikowanych do analizy nie posiadało słów kluczowych. Najczęściej pojawiające się słowa kluczowe w publikacjach wyłonionych z baz danych to: crowdsourcing (15), innovation (6), open (6), participation (6), democracy(5), planning (5), media (5).

W dalszej kolejności, na podstawie słów kluczowych, streszczeń, wyodrębniono najczęściej wykorzystywane przez badawczy pespektywy badawcze. Pozwala to na zidentyfikowanie metodologicznych wartości, które są ważne z uwagi na rozwiązywanie 
problemów $^{52}$ oraz określenie nurtu badawczego rozwijającego badane publikacje. Tym samym wyróżniono następujące perspektywy badawcze, tj. zarządzanie innowacjami (otwarte innowacje), kapitał tłumu oraz zarządzanie partycypacyjne (tab. 3).

Tabela 3. Perspektywy badawcze nad crowdsourcingiem w organizacjach publicznych

\begin{tabular}{|c|c|c|c|}
\hline Autor/autorzy & $\begin{array}{c}\text { Perspektywa } \\
\text { badawcza }\end{array}$ & Zakres tematyczny & Poziom analizy \\
\hline \multirow{2}{*}{$\begin{array}{l}\text { Brabham, Sanchez, } \\
\text { Bartholomew, 2009; } \\
\text { Chen, 2016; Oomen, } \\
\text { Aroyo, 2011;Seltzer, } \\
\text { Mahmoudi, 2012; Stiver et } \\
\text { al., 2014; Bayus, 2012; } \\
\text { Basto, Flavin, Patino, } \\
\text { 2010; Dunn, Hedges, } \\
\text { 2012; Budhathoki, } \\
\text { Haythornthwaite, } \\
\text { 2012;Lönn, Uppström, } \\
\text { 2013; Sinha, 2008 }\end{array}$} & \multirow[b]{2}{*}{$\begin{array}{l}\text { Perspektywa } \\
\text { organizacyjna }\end{array}$} & \multirow[b]{2}{*}{$\begin{array}{l}\text { Kapitał thumu, zarządzanie } \\
\text { partycypacyjne, zarządzanie } \\
\text { innowacjami }\end{array}$} & $\begin{array}{l}\text { uczestnik } \\
\text { (motywacja, } \\
\text { zachowanie) }\end{array}$ \\
\hline & & & $\begin{array}{l}\text { organizacja } \\
\text { (przyjęcie, } \\
\text { wdrożenie, } \\
\text { koordynacja, } \\
\text { zarządzanie, jakość, } \\
\text { ocena) }\end{array}$ \\
\hline $\begin{array}{l}\text { Minner, Holleran, Roberts, } \\
\text { Conrad, 2015; Green, } \\
\text { 2016; Estermann, } 2016\end{array}$ & $\begin{array}{l}\text { Perspektywa } \\
\text { techniczna }\end{array}$ & $\begin{array}{l}\text { Oprogramowanie, funkcje } \\
\text { techniczne, interfejs } \\
\text { użytkownika, } \\
\text { uwierzytelnianie } \\
\text { użytkownika, profile } \\
\text { użytkownika, historia } \\
\text { śledzenia, mechanizmy } \\
\text { płatności za pomysły } \\
\end{array}$ & $\begin{array}{l}\text { system } \\
\text { (zachęta, } \\
\text { mechanizmy, } \\
\text { technologia) }\end{array}$ \\
\hline \multirow{2}{*}{$\begin{array}{l}\text { Mergel, 2015; } \\
\text { Agapie, Teevan, Monroy- } \\
\text { Hernandez, 2015; } \\
\text { Hudson-Smith et al., 2009; } \\
\text { Schwarz, 2016; Cullina, } \\
\text { Conboy, Morgan, 2015; } \\
\text { Hiltunen, 2011;Bott, } \\
\text { Young, 2012; Aitamurto, } \\
\text { Landemore, 2013; Byren, } \\
2013\end{array}$} & \multirow[b]{2}{*}{$\begin{array}{l}\text { Perspektywa } \\
\text { procesu }\end{array}$} & \multirow{2}{*}{$\begin{array}{l}\text { Struktury, typologie, procesy } \\
\text { organizacyjne, składanie, } \\
\text { dystrybucja, akceptowanie } \\
\text { pomysłów thumu, określenie } \\
\text { i podział zadań dla tłumu, } \\
\text { interakcje pomiędzy } \\
\text { organizacją a tłumem }\end{array}$} & $\begin{array}{l}\text { uczestnik } \\
\text { (motywacja) }\end{array}$ \\
\hline & & & $\begin{array}{l}\text { organizacja } \\
\text { (koordynacja, } \\
\text { motywacja } \\
\text { pracownika) }\end{array}$ \\
\hline
\end{tabular}

Źródło: opracowanie własne. Stan na dzień: 24.04.2016.

Badania nad crowdsourcingiem w organizacjach publicznych prowadzone były głównie z perspektywy organizacyjnej (ponad 47\% z 23 publikacji o charakterze empirycznym). Koncentrowały się one wokół wykorzystania inteligencji zbiorowości ${ }^{53}$, potencjału

52 M. Lisiński, Analiza metodologii nauk o zarzadzaniu, (w:) Rozwój koncepcji i metod zarządzania, J. Czekaj, M. Lisiński (red.), Fundacja Uniwersytetu Ekonomicznego w Krakowie, Kraków 2011.

${ }^{53}$ D.C. Brabham, Crowdsourcing the Public Participation Process for Planning Projects, "Planning Theory"2009, 8(3); K. Chen, The Power of Citizens' Voices in Democracy-Examining the impact of 
crowdsourcingu $^{54}$, otwartych innowacji ${ }^{55}$, wyzwań i szans w kontekście zaangażowania obywateli $^{56}$, negatywnego wpływu crowdsourcingu na implementację pomysłów ${ }^{57}$, potencjału organizacji publicznych do generowania pomysłów ${ }^{58}$, motywacji do korzystania $\mathrm{z}$ wiedzy tłumu ${ }^{59}$, partycypacji obywateli ${ }^{60}$, trendów konsumenckich ${ }^{61}$.

W drugiej grupie artykułów (ponad 39\% publikacji) znajdowały się te ujmujące crowdsourcing z perspektywy procesowej. Można tu wyszczególnić następujące problemy: fazy procesu crowdsourcingu ${ }^{62}$, interakcji i komunikacji pracowników $\mathrm{z}$ tłumem ${ }^{63}$ oraz sposobów jego zaangażowania ${ }^{64}$, procesów organizacyjnych ${ }^{65}$, struktur zarządzania systemów crowdsourcingowych $^{66}$, zasad polityki crowdsourcingowej ${ }^{67}$, typologii ${ }^{68}$.

civic input on crowdsourced policymaking, http://programme.exordo.com/irspm2016/delegates/ presentation $/ 269 /$.

54 J. Oomen, L. Aroyo,Crowdsourcing in the Cultural Heritage Domain: Opportunities and Challenges, Proceedings C\&T 11, 2011. http://www.iisi.de/fileadmin/IISI/upload/2011/ p138_oomen.pdf.

5 E. Seltzer, Mahmoudi D., Citizen Participation, Open Innovation, and Crowdsourcing: Challenges and Opportunities for Planning, "Journal of Planning Literature" 2012, 28(1).

${ }^{56}$ A. Stiver, L. Barroca, M. Petre, M. Richards, D. Roberts, Civic crowdfunding: how do offline communities engage online?,British HCI Proceedings of the 2015 British HCI Conference, 2015.

${ }^{57}$ B. L. Bayus, Crowdsourcing New Product Ideas Over Time: An Analysis of Dell's Ideastorm Community, UNC Kenan-Flagler Research Paper 2012, 5.

${ }^{58}$ D. Basto, T. Flavin, C. Patino, Crowdsourcing Public Policy Innovation, Working Paper, Heinz College Carnegie Mellon University 2010.

${ }^{59}$ S. Dunn, M. Hedges, Crowd-Sourcing Scoping Study: Engaging the Crowd with Humanities Research, Centre for e-Research, Department of Digital Humanities, King's College, London 2012; N. R. Budhathoki, C. Haythornthwaite, Motivation for Open Collaboration: Crowd and Community Models and the Case of Open Street Map, "American Behavioral Scientist" 2012, 57(5).

${ }^{60}$ C. M. Lönn, E. Uppström, The Promise of a Crowd, Proceedings of the Nineteenth Americas Conference on Information Systems, Chicago, Illinois, 2013.

${ }^{61}$ R. Sinha, The silent innovators, "One India, One People" 2008, 15-17.

${ }^{62}$ I. Mergel, Opening Government: Designing Open Innovation Processes to Collaborate With External Problem Solvers, "Social Science Computer Review"2015, 33(5).

${ }^{63}$ E. Agapie, J. Teevan, A. Monroy-Hernández, Crowdsourcing in the Field: A Case Study Using Local Crowds for Event Reporting, Human Computation (HCOMP), AAAI - Association for the Advancement of Artificial Intelligence: August 2015; A. Hudson-Smith, M. Batty, A. Crooks, R. Milton, Mapping for the masses accessing Web 2.0 through crowdsourcing, "Social Science Computer Review" 2008, 27 (4); J. A. Schwarz, Public Service Broadcasting and Data-Driven Personalization: A View from Sweden, "Television\&New Media" 2016, 17(2).

${ }^{64}$ E. Cullina, K. Conboy, L. Morgan, Measuring the Crowd - A Preliminary Taxonomy of Crowdsourcing Metrics, Proceedings of the 11th International Symposium on Open Collaboration, 2015.

${ }^{65}$ E. Hiltunen, Crowdsourcing the future: The foresight process at finpro, "Journal of Futures Studies" 2011, 16(1).

${ }^{66}$ M. Bott, G. Young, The Role of Crowdsourcing for Better Governance in International Development, Praxis: the Fletcher Journal of Human Security 2012, 27.

${ }^{67}$ T. Aitamurto, H. Landemore, Democratic participation and deliberation in crowdsourced legislative processes: The case of the law on offroad traffic in Finland, C\&T'13, Workshop: Largescale idea management and deliberation systems, 2013.

${ }^{68}$ E. Byren, Internal crowdsourcing for innovation development: How multinational companies can obtain the advantages of crowdsourcing utilising internal resources http://publications.lib.chalmers.se/records/fulltext/181969/181969.pdf 
Ostatnia, trzecia grupa publikacji wyróżnia perspektywę techniczną - gdzie znalazło się ponad 13\% artykułów. Koncentrują się one na systemach informacyjnych zwiększających zaangażowanie obywateli ${ }^{69}$, konsekwencji zastosowania platform ${ }^{70}$, social media $^{71}$.

Większości zakwalifikowanych do analizy treści publikacji stanowiły te o charakterze empirycznym (23 publikacje) - w szczególności studiaprzypadku czy opisy zdarzeń (22 publikacje). W jednym przypadku badacze zdecydowali się na metodę ilościową (technika: kwestionariusz ankiety). Liczba publikacji teoretycznych wyniosła 7, przy czym większość $\mathrm{z}$ nich to systematyczne przeglądy literatury. Takie wyodrębnienie może stanowić rekomendację co do metody zastosowanej przez przyszłych badaczy. Dodatkowo, analiza publikacji wskazuje, że nie są one wolne od ograniczeń poznawczych i metodycznometodologicznych. Brakuje badań, które w sposób całościowy podejmowałyby problematykę crowdsourcingu, ze szczególnym uwzględnieniem wiedzy znajdującej się w thumie.

W odniesieniu do ośrodków badawczych, które najczęściej analizują i badają zagadnienie crowdsourcingu $\mathrm{w}$ organizacjach publicznych prym wiodą kraje europejskie (14 publikacji). W Stanach Zjednoczonych również obserwuje się spore zainteresowanie tą problematyką: 13 publikacji, przy czym najwięcej publikacji pochodziło z Wielkiej Brytanii (4 artykuły). W dalszej kolejności wyniki przedstawiały się następująco: Szwajcaria (2), Szwecja (2), Niemcy (2), Hiszpania (1), Holandia (1), Finlandia (1), Irlandia (1). Najmniej opracowań opublikowały ośrodki badawcze z Chin (2) oraz Kanady (1).

\subsection{Analiza treści}

Zgromadzona baza literaturowa została poddana pogłębionej analizie treści, co pozwoliło na ocenę dotychczasowego dorobku $\mathrm{z}$ uwzględnieniem jego przydatności, jakości oraz sformułowanie ram koncepcyjnych dalszych badań nad tym pojęciem. Dodatkowo umożliwia wyłonienie luk poznawczych, wskazanie obszarów dalszych badań oraz rekomendacji dla przyszłych badaczy.

Po pierwsze, aktualność badań nad crowdsourcingiem oraz dojrzałość pola badawczego. Analiza prac teoretycznych oraz empirycznych pozwala na stwierdzenie o aktualności badań nad crowdsourcigiem $w$ organizacjach publicznych. Pierwsza praca poświęcona crowdsourcingowi pojawiła się stosunkowo niedawno, w 2006 roku za sprawą artykułu J. Howe'a „The Rise of Crowdsourcing”. Należy jednak podkreślić, że już w 1989 roku została uruchomiana pierwsza platforma crowdsourcingowa - w mieście Santa Monica w Kalifornii (Public Electronic Network). Była to sieć obsługiwana przez władze miasta i wykorzystywana do społeczeństwo. Platforma składała się $\mathrm{z}$ gromadzenia ogłoszeń publicznych, harmonogramów, wymiany e-maili pomiędzy urzędnikami a społeczeństwem, była także swoistym forum dyskusyjnym poświęconym problemom miasta. Natomiast od 2009 roku obserwuje się stałe zainteresowanie badaczy tą problematyka $\mathrm{z}$ uwzględnieniem sektora

\footnotetext{
${ }^{69}$ J. Minner, M. Holleran, A. Roberts, J. Conrad, Capturing volunteered historical information: Lessons from development of a local government crowdsourcing tool, "International Journal of EPlanning" 2015, 4(1).

${ }^{70}$ A. E. Green, Implications of technological change and austerity for employability in urban labour markets, "Urban Studies February"2016, 23.

${ }^{71}$ Esterman B., OpenGLAM in Practice - How Heritage Institutions Appropriate the Notion of Openness 2016,

http://programme.exordo.com/irspm2016/delegates/presentation/47/.
} 
publicznego. Można zatem stwierdzić, że rozważane pole badawcze znajduje się w fazie wczesnego wzrostu, co stanowi wysoce aktualny obszar rozważań ${ }^{72}$.

Po drugie, stan wiedzy dotyczący crowdsourcingu w organizacjach publicznych. Analiza treści wykazała, że większość publikacji analizuje crowdsourcing na trzech poziomach: organizacji (zasady, dostosowanie do misji i celów organizacji, wsparcie kierownictwa, motywatory), projektu (typ zadania) oraz indywidualnym (odporność pracowników na wiedzę zewnętrzną, postawy pracowników, korzyści dla pracowników, motywacja tłumu). Jednakże głównymi obszarami zainteresowań badaczy są korzyści z crowdsourcingu. Jednakże, analiza dotychczasowych artykułów teoretycznych ${ }^{73}$ oraz przeprowadzonych badań empirycznych wskazuje, że wciąż brakuje szczegółowej konceptualizacji oraz operacjonalizacji. Jak pokazują wyniki systematycznego przeglądu literatury, crowdsourcing pomimo rosnącego zainteresowania, badacze nadal są raczej zainteresowani poszukiwaniem konkretnych zastosowań i korzyści z crowdsourcingu. Jednakże nie dostrzega się także sposobów na badanie skuteczności kampanii crowdsourcingowych, co uniemożliwia wdrażanie nowych aplikacji $^{74}$. Ponadto pojawia się próba połączenia crowdsourcingu $\mathrm{z}$ otwartością organizacji na nową wiedzę zewnętrzną ${ }^{75}$. Nie zostało to także w sposób dostateczny rozstrzygnięte. Co według autorki może stanowić interesująca lukę poznawczą. Jej wyjaśnienie może prowadzić do lepszego zrozumienia istoty i znaczenia crowdsourcing dla wszystkich zainteresowanych stron. Nie bez znaczenia jest rola pracowników - nowe rozwiązania nie zostaną przyjęte, jeśli pracownicy nie dostrzegają korzyści ${ }^{76}$.

Po trzecie, rekomendowane kierunki rozwoju pola badawczego (tabela 4). W oparciu o wyniki systematycznego przeglądu literatury, można wyłonić trzy kierunki dalszych badań: (1) tłum, (2) inicjator, (3) proces.

${ }^{72}$ D.C. Brabham, Crowdsourcing in the Public Sector, Georgetown University Press 2015; D.C. Brabham, Crowdsourcing the Public Participation Process for Planning Projects, "Planning Theory"2009, 8(3); D. Hilgers, Ch. Ihl, Citizensourcing - Applying the Concept of Open Innovation to the Public Sector, "International Journal of Public Participation" 2010, 4(1); H. Shepherd, Crowdsourcing, "Contexts" 2012,11(10); E. Estelles-Arolas, F. Gonzalez-Ladron-de-Guevara, Towards an Integrated Crowdsourcing Definition,"Journal of Information Science" 2012, 38(2); A. Kittur, J.V. Nickerson, M. S. Bernstein, E. Gerber, A.D. Shaw, J. Zimmerman, M. Lease, J. Horton, The future of crowd work, A. Bruckman, S. Counts, C. Lampe, L. G. Terveen (eds.), Proceedings of the 2013 conference on Computer supported cooperative work, 2013; I. Mergel, Opening Government: Designing Open Innovation Processes to Collaborate With External Problem Solvers, "Social Science Computer Review"2015, 33(5).

73 P. Whitla, Crowdsourcing and its Application in Marketing Activities, "Contemporary Management Research" 2009, 5(1)

${ }^{74}$ D. C. Brabham, K. M. Ribisl, T. R. Kirchner, J. M. Bernhardt, Crowdsourcing Applications for Public Health, "American Journal of Preventive Medicine"2014, 46(2).

${ }^{75} \mathrm{H}$. W. Chesbrough, A. K. Crowther, Beyond high tech: early adopters of open innovation in other industries, "R \& D Management" 2006, 36(3); H. W. Chesbrough, Business model innovation: opportunities and barriers, "Long Range Planning" 2010, 43; L. Huston, N. Sakkab, Connect and Develop. Inside Procter \& Gamble's new model for innovation, "Harvard Business Review" 2006, march; J. Feller, P. Finnegan, J. Hayes, P. O'Reilly, "Orchestrating” sustainable crowdsourcing: A characterisation of solver brokerages, "Journal of Strategic Information Systems" 2012, 21(3); A. Majchrzak, A. Malhotra, Towards an information systems perspective and research agenda for open innovation crowdsourcing, Journal of Strategic Information Systems" 2013, 22.

76 C.A. Louis, Organizational perspectives of open innovation in government, iConference Proceedings, 2013. 
Tabela 4. Rekomendowane kierunki badań nad crowdsourcingiem w organizacjach publicznych

\begin{tabular}{|l|l|}
\hline \multicolumn{1}{|c|}{ Autor/autorzy } & \multicolumn{1}{|c|}{ Kierunki badań } \\
\hline Brabham, Sanchez, Bartholomew, & Sposoby zaangażowania tłumu. \\
2009; Seltzer, Mahmoudi, 2012; & \\
Cullina, Conboy, Morgan, 2015; & \\
Minner, Holleran, Roberts, Conrad, & \\
2015; Bott, Young, 2012 & \\
\hline Toubia, 2006; Shah, 2006; Basto, & Mechanizmy nagradzania i sprzężenia zwrotnego. \\
Flavin, Patino, 2010; Jeppesen, & \\
Lakhani, 2010; Dunn, Hedges, 2012; & \\
Bayus, 2012; Byren, 2013; Aitamurto, & \\
Landemore, 2013 & \\
\hline Lönn, Uppström, 2013; Schwarz, 2016 & Korzyści dla obywateli. \\
\hline Oomen, Aroyo, 2011 & Korzyści dla organizacji. \\
\hline Sinha, 2008; Hudson-Smith et al., & Zasady uczestnictwa. \\
2009; Budhathoki, Haythornthwaite, & \\
2012; Lönn, Uppström, 2013; Stiver et & \\
al., 2014 & \\
\hline Hiltunen, 2011; Lönn, Uppström, & Gotowość organizacji do crowdsourcingu. \\
2013; Mergel, 2015; Minner, Holleran, & \\
Roberts, Conrad, 2015; & \\
Estermann, 2016; Green, 2016; Chen, & \\
2016 & \\
\hline Agapie, Teevan, Monroy-Hernandez, & Komunikacja na linii urząd-społeczność wirtualna. \\
2015 & \\
\hline
\end{tabular}

Źródło: opracowanie własne. Stan na dzień: 24.04.2016.

A zatem, na podstawie przeprowadzonego systematycznego przeglądu literatury, można wskazać, że brak jest prac naukowych (teoretycznych i empirycznych), które analizują crowdsourcing w organizacji publicznej we wszystkich zidentyfikowanych perspektywach: indywidualnej, organizacyjnej oraz procesowej. Wielu autorów wskazuje na konieczność zwrócenia uwagi na to, kto tworzy tłum, dalej jakie posiada umiejętności czy kompetencje. Drugi kierunek badań łączy crowdsourcing z korzyściami, jakie może osiągnąć organizacja. Brak także badań łączących crowdsourcing $\mathrm{z}$ otwartymi innowacjami ${ }^{77}$. Wreszcie trzeci kierunek badań wskazuje, że powinno się przeanalizować gotowość organizacji do przyjęcia wiedzy pochodzącej z tłumu, partycypacji obywateli czy sposobów zaproszenia tłumu do działania. Jednocześnie kierunki te opisane i badane są $\mathrm{w}$ literaturze tylko $\mathrm{w}$ sposób fragmentaryczny, wybiórczy. Mogą zatem stanowić zalecane kierunki dalszych badań nad crowdsourcigniem w organizacjach publicznych. Dodatkowo, przyszłe wysiłki badawcze powinny skoncentrować się na opracowaniu ram koncepcyjnych warunków organizacyjnych $\mathrm{w}$ organizacjach publicznych, taksonomii wymiarów, zaleceń dotyczących motywowania

\footnotetext{
${ }^{77}$ V. Chanal, M.L. Caron-Fasan, How to invent a new business model based on crowdsourcing: The crowdspirit $R$ case, EURAM Conference, 2008; E. Schenk, C. Guittard, Crowdsourcing: What can be Outsourced to the Crowd, and Why?, "HAL: Sciences de l'Homme et de la Société" 2009.
} 
tłumu i pracowników organizacji publicznych. Aktualnie tak szerokie i holistyczne ujęcie crowdsourcingu w organizacjach publicznych jest poza zakresem zainteresowań badaczy.

\section{ZAKOŃCZENIE}

Wyniki systematycznego przeglądu literatury $\mathrm{w}$ kontekście crowdsourcingu $\mathrm{w}$ organizacjach publicznych pozwalają na wyciągnięcie kilku wniosków. Stan wiedzy, pomimo tendencji wzrostowej, nadal jest dość skromny i fragmentaryczny. Nie jest także wolny od ograniczeń. Przegląd ograniczeń dotychczasowych badań oraz rekomendowanych przez autorów kierunków dalszych badań pozwalają na wskazanie propozycji kierunków przyszłych wyzwań badawczych: (1) ujednolicenie i uszczegółowienie konceptualizacji pojęcia; (2) badanie crowdsourcingu z uwzględnieniem trzech perspektyw: organizacyjnej, technicznej oraz procesowej; (3) pomiar skuteczności kampanii crowdsourcingowych; (4) ustalenie związków z otwartymi innowacjami; (5) rozpoznanie roli pracowników dla sukcesu projektów crowdsourcingowych; (6) opracowanie ram koncepcyjnych warunków organizacyjnych w organizacjach publicznych. Dodatkowo, przyszłe wysiłki badawcze powinny skoncentrować się na motywacji tłumu oraz organizacji publicznej do pozyskiwania wiedzy z thumu. W literaturze widoczny jest deficyt badan naukowych koncentrujących się na zarządzaniu wiedzą w crowdsourcingu. Sugeruje się, aby przyszłe badania empiryczne były prowadzone z wykorzystaniem studium przypadku.

\section{LITERATURA}

[1] Agapie E., Teevan J., Monroy-Hernández A., Crowdsourcing in the Field: A Case Study Using Local Crowds for Event Reporting, Human Computation (HCOMP), AAAI - Association for the Advancement of Artificial Intelligence: August 2015.

[2] Agrawal A.,Catalini Ch., Goldfarb A., The Simple Economics of Crowdfunding, Innovation Policy and the Economy, University Press, Chicago 2013.

[3] Aitamurto T., LandemoreH., Democratic participation and deliberation in crowdsourced legislative processes: The case of the law on offroad traffic in Finland, C\&T'13, Workshop: Large-scale idea management and deliberation systems, 2013.

[4] Albors J., Ramos J.C., Hervas J.L., New learning network paradigms: Communities of objectives, crowdsourcing, wikis and open source, "International Journal of Information Management" 2008, 28.

[5] Albury D., Fostering innovation in public services, "Public Money and Management" 2005, 25.

[6] Alford J., Engaging public sector clients: from service delivery to coproduction, Palgrave Macmillan, Basingstoke 2009.

[7] Alonso O., Lease M., Crowdsourcing for information retrieval: Principles, methods, and applications, Tutorial at the 34th annual ACM SIGIR conference, 2011.

[8] AsgarkhaniM.,The effectiveness of e-Service in the Public Sector: A Local Government Perspective, Proceedings of the European Conference on Electronic Government, 2005.

[9] Basto D., Flavin T., Patino C., Crowdsourcing Public Policy Innovation, Working Paper, Heinz College Carnegie Mellon University 2010. 
[10] Bayus B.L., Crowdsourcing New Product Ideas Over Time: An Analysis of Dell's Ideastorm Community, UNC Kenan-Flagler Research Paper 2012, 5.

[11] Borins S., The Challenge of Innovating in Government, PricewaterhouseCoopers Endowment for the Business of Government, Arlington: VA 2001.

[12] Bott M., Young G., The Role of Crowdsourcing for Better Governance in International Development, Praxis: the Fletcher Journal of Human Security 2012, 27.

[13] Bowler S., Donovan T.A., Demanding Choices: Opinion, Voting, and Direct Democracy, AnnArbor: University of Michigan Press 2000.

[14] Brabham D.C., Crowdsourcing as a Model for Problem Solving: An Introduction and Cases', Convergence, "The International Journal of Research into New Media Technologies" 2008, 14(1).

[15] Brabham D.C., Crowdsourcing the Public Participation Process for Planning Projects, "Planning Theory"2009, 8(3).

[16] Brabham D.C., Crowdsourcing in the Public Sector, Georgetown University Press 2015.

[17] Brabham D.C., Ribisl, K.M., Kirchner, T.R., Bernhardt, J. M., Crowdsourcing Applications for Public Health, "American Journal of Preventive Medicine"2014, 46(2).

[18] Brabham D.C., Sanchez T.W., Bartholomew K., Crowdsourcing public participation in transit planning: preliminary results from the next stop design case,TRB 89th Annual Meeting Compendium, 2010.

[19] Budhathoki N. R., Haythornthwaite C., Motivation for Open Collaboration: Crowd and Community Models and the Case of OpenStreetMap, "American Behavioral Scientist" 2012, 57(5).

[20] Buecheler T., Sieg J.H., Füchslin R.M., Pfeifer R., Crowdsourcing, Open Innovation and Collective Intelligence in the Scientific Method: A Research Agenda and Operational Framework". Proceedings of the Twelfth International Conference on the Synthesis and Simulation of Living Systems, Mass: MIT Press, Cambridge2010.

[21] Burger-Helmchen T., Pénin J., The limits of crowdsourcing inventive activities: What do transaction cost theory and the evolutionary theories of the firm teach us?,Workshop on Open Source Innovation, Strasbourg, France 2010.

[22] Byren E., Internal crowdsourcing for innovation development: How multinational companies can obtain the advantages of crowdsourcing utilising internal resources

[23] Http://publications.lib.chalmers.se/records/fulltext/181969/181969.pdf

[24] Chen K., The Power of Citizens' Voices in Democracy-Examining the impact of civic input on crowdsourced policymaking,http://programme.exordo.com/ irspm2016/delegates/presentation/269/.

[25] Chanal V., Caron-FasanM. L., How to invent a new business model based on crowdsourcing: The crowdspirit $R$ case, EURAM Conference, 2008.

[26] Chesbrough H.W., Open Innovation: The New Imperative for Creating and Profiting from Technology, Boston: Harvard Business School Press, Boston 2003.

[27] Chesbrough H.W., Business model innovation: opportunities and barriers, "Long Range Planning" 2010, 43. 
[28] Chesbrough H.W., Crowther A.K., Beyond high tech: early adopters of open innovation in other industries, "R \& D Management" 2006, 36(3).

[29] Cullina E., Conboy K., Morgan L., Measuring the Crowd - A Preliminary Taxonomy of Crowdsourcing Metrics, Proceedings of the 11th International Symposium on Open Collaboration, 2015.

[30] Czakon W., Dynamika więzi międzyorganizacyjnych przedsiębiorstwa, Wydawnictwo Akademii Ekonomicznej w Katowicach, Katowice 2007.

[31]Czakon W., Metodyka systematycznego przegladu literatury, „Przegląd Organizacji” 2011, 3.

[32] DiPalantino D., Vojnović M., Crowdsourcing and all-pay auctions, Proceedings of the 10th ACM conference on Electronic commerce 2009.

[33] Dunleavy P., Hood Ch., From old public administration to new public management, "Public Money \& Management" 1994, 14(3).

[34] Doan A., Ramakrishnan R., Halevy A. Y., Crowdsourcing systems on the WorldWide Web, Communications of the ACM 2011, 54(86).

[35] Dunn S., Hedges M., Crowd-Sourcing Scoping Study: Engaging the Crowd with Humanities Research, Centre for e-Research, Department of Digital Humanities, King's College, London 2012.

[36] Edvinsson L., Malone M.S., Kapitat intelektualny, Wydawnictwo PWN,Warszawa 2011.

[37] Estelles-Arolas E., Gonzalez-Ladron-de-Guevara F., Towards an Integrated Crowdsourcing Definition,"Journal of Information Science"2012, 38(2).

[38] Esterman B., OpenGLAM in Practice - How Heritage Institutions Appropriate the Notion of Openness 2016,

[39] Http://programme.exordo.com/irspm2016/delegates/presentation/47/.

[40] Feller J., Finnegan P., Hayes J., O'Reilly P. 2012, "Orchestrating” sustainable crowdsourcing: A characterisation of solver brokerages, "Journal of Strategic Information Systems" 2012, 21(3).

[41]Ford J.K., Smith E. M., Weissbein D. A., Gully S. M., Salas E.,Relationships of goal orientation, metacognitive activity, and practice strategies with learning outcomes and transfer, "Journal of Applied Psychology"1998, 83(2).

[42] Fraternali P., Castelletti A., Soncini-Sessa R., Ruiz V.C., Rizzoli A.E., Putting humans in the loop: Social computing for Water Resources Management,"Environmental Modelling \& Software"2012, 37.

[43] Green A.E., Implications of technological change and austerity for employability in urban labour markets, "Urban Studies February"2016, 23.

[44] Harrison R., Crowdfunding and the revitalisation of the early stage risk capital market: catalyst or chimera, "Venture Capital"2013 15(4).

[45] Heer J., Bostok M., Crowdsourcing graphical perception: using mechanical turk to assess visualization design, Proceedings of the 28th international conference on Human factors in computing systems, 2010

[46] Heymann P., Garcia-Molina H.,Turkalytics: analytics for human computation, Proceedings of the 20th international conference on World wide web, 2011

[47] Hickley M., The Grounds for Citizen Engagement and the Roles of Planners, Saarbruecken: VDM, 2008.

[48] Hilgers D., Ihl Ch., Citizensourcing - Applying the Concept of Open Innovation to the Public Sector, "International Journal of Public Participation" 2010, 4(1). 
[49] Hiltunen E., Crowdsourcing the future: The foresight process at finpro, "Journal of Futures Studies" 2011, 16(1).

[50] Hirth M., Hoßfeld T., Tran-Gia P., Anatomy of a crowdsourcing platform-using the example of microworkers.com, Innovative Mobile and Internet Services in Ubiquitous Computing (IMIS), Fifth International Conference on, 2011.

[51] Holzer M., Kloby K., Public performance measurement. An assessment of the state ofthe-art and models for citizen participation, "International Journal of Productivity and Performance Management" 2005, 54(7).

[52] Howe J., The rise of crowdsourcing, "Wired Magazine" 2006, 14(6).

[53] Howe J., Crowdsourcing: Why the Power of the Crowd Is Driving the Future of Business, Crown Publishing Group, New York 2008.

[54] Hudson-Smith A., Batty M., Crooks A., Milton R., Mapping for the masses accessing Web 2.0 through crowdsourcing, "Social Science Computer Review" 2008, 27 (4).

[55] Huston L., Sakkab N., Connect and Develop. Inside Procter \& Gamble's new model for innovation, "Harvard Business Review"2006, march.

[56] Gassmann O., Crowdsourcing - Innovationsmanagement mit Schwarmintelligenz, Hanser-Verlag,München 2012.

[57] Gioacchino La V., Cisternino A., Collaborative Workforce, Business Process Crowdsourcing as an Alternative ofBPO, Current Trends in Web Engineering. 10th International Conference on Web Engineering, Springer-Verlag, Berlin Heidelberg 2010.

[58] Grier D.A., Error identification and correction in human computation: Lessons from the WPA, AAAI Workshop Human Computation Workshop HCOMP, 2011.

[59] Grundström Ch., Öberg Ch., ÖhrwallRönnbäck A.,View and management of innovativeness upon succession in family-owned SMEs, "International Journal of InnovationManagement" 2011, 15(3).

[60] Jenkins H., Purushotma R., Clinton K., Weigel M., Robison A. J., Confronting the Challenges of Participatory Culture: Media Education for the 21st Century, The MacArthur Foundation, Chicago 2006,

[61] Jeppesen L.B., Lakhani K. R.,Marginality and Problem Solving Effectiveness in Broadcast Search, "Organization Science” 2010, 21(5)

[62] Kittur A., Chi E.H., Suh B., Crowdsourcing for Usability: Using Micro-Task Markets for Rapid, Remote, and Low-cost User Measurements, Proceedings of CHI, 2008.

[63] Kittur A., Nickerson J.V., Bernstein M.S., Gerber E., Shaw A.D., Zimmerman J., Lease M., Horton J., The future of crowd work, A. Bruckman, S. Counts, C. Lampe, L.G. Terveen (eds.), Proceedings of the 2013 conference on Computer supported cooperative work, 2013.

[64] Kazai G., In search of quality in crowdsourcing for search engine evaluation, "Advances in Information Retrieval" 2011, 6611.

[65] Kleemann F., Günter Voß G., Rieder K., Un(der)paid Innovators: The Commercial Utilization of Consumer Work through Crowdsourcing, "Science, Technology\& Innovation Studies" 2008, 4 (1).

[66] La Vecchia G., Cisternino A., Collaborative Workforce, Business Process Crowdsourcing as an Alternative ofBPO. [In:] Current Trends in Web 
Engineering, 10th International Conference on Web Engineering, F. Daniel, F.M. Facca (eds.), Springer-Verlag, Berlin Heidelberg 2010.

[67] Leimeister J.M., Collective intelligence, "Business and Information Systems Engineering" 2010, 4(2).

[68] Leimeister J.M., Zogaj S., Neue Arbeitsorganisation durch Crowdsourcing: Eine Literaturstudie, Hans Böckler Stiftung, Düsseldorf 2013.

[69] Levy Y., Ellis T.J., A systems approach to conduct an effective literaturereview in support of information systems research, "Informing Science:International Journal of an Emerging Transdiscipline" 2006, 9.

[70]Ling P., An Empirical Study of Social Capital in Participation in Online crowdsourcing, "Computer" 2010, 7(9).

[71] Lister R., Citizen in Action: Citizenship and community development in Northern Ireland Context, "Community Development Journal" 1998, 33(3).

[72] Lisiński M., Analiza metodologii nauk o zarządzaniu, (w:) Rozwój koncepcji $i$ metod zarządzania, J. Czekaj, M. Lisiński (red.), Fundacja Uniwersytetu Ekonomicznego w Krakowie, Kraków 2011.

[73] Liu E., Porter T.,Culture and KM in China, „VINE” 2010, 40(3/4).

[74] Lodge M., Wegrich K., Crowdsourcing and Regulatory Reviews: A New Way of Challenging Red Tape in British Government?, "Regulation\&Governance" 2015, $9(1)$.

[75]Lönn C.M., Uppström E., The Promise of a Crowd, Proceedings of the Nineteenth Americas Conference on Information Systems, Chicago, Illinois, 2013.

[76]Louis C.A., Organizational perspectives of open innovation in government, iConference Proceedings, 2013.

[77] Majchrzak A., Malhotra A., Towards an information systems perspective and research agenda for open innovation crowdsourcing, Journal of Strategic Information Systems" 2013, 22.

[78] Mazzola D., Distefano A., Crowdsourcing and the participacion process for problem solving: the case of BP, VII Conference of the Italian Chapter of AIS, Information technology and Innovation trend in Organization, 2010.

[79] McGuire M., Collaborative Public Management: Assessing What We Know and How We Know It,"Public Administration Review" 2006, 66(1).

[80] Mergel I., Opening Government: Designing Open Innovation Processes to Collaborate With External Problem Solvers, "Social Science Computer Review" 2015, 33(5).

[81] Mikuła B., Organizacje oparte na wiedzy, Wydawnictwo Akademii Ekonomicznej w Krakowie, Kraków 2006.

[82] Minner J., Holleran M., Roberts A., Conrad J., Capturing volunteered historical information: Lessons from development of a local government crowdsourcing tool, "International Journal of E-Planning" 2015, 4(1).

[83] Noveck B.S., Wiki Government: How Technology Can Make Government Better, Democracy Stronger, and Citizens More Powerful, Brookings Institution Press, Washington, D.C 2009.

[84] OECD. Promise and Problems of E-Democracy: Challenges of Online Citizen Engagement, OECD Publications, Paris 2004.

[85] OECD. Open government legislation, OECD Publishing, Paris 2009. 
[86] Oliveira F., Ramos I., Santos L., Definition of a crowdsourcing Innovation Service for the European SMEs, [In:] F. Daniel, F. M., Facca, Current Trends in Web Engineering, Springer, Berlin/Heidelberg 2010.

[87] Oomen J., Aroyo L., Crowdsourcing in the Cultural Heritage Domain: Opportunities and Challenges, Proceedings C\&T 11, 2011. http://www.iisi.de/fileadmin/IISI/upload/2011/p138_oomen.pdf.

[88] Pedersen J., Kocsis D., Tripathi A., Tarrell A., Weerakoon A., Tahmasbi N., Xiong J., Deng W., Oh O., De Vreede G. J., Conceptual Foundations of Crowdsourcing: A Review of IS Research, 46th Hawaii International Conference on System Sciences (HICSS), 2013.

[89] Pelzer C., Crowdsourcing Terminologie, 2011.

[90] Http://www.Crowdsourcingblog.de.

[91] Prpić J., Shukla P., The Theory of Crowd Capital, Proceedings of the Hawaii International Conference on System Sciences \#46, 2012.

[92] Prpić J., Shukla P., Kietzmann J. H., McCarthy I. P., How to Work a Crowd: Developing Crowd Capital through Crowdsourcing, "Business Horizons" 2015, 8(1).

[93] Poetz M.K., Schreier M., The Value of Crowdsourcing: Can Users Really Compete with Professionals in Generating New Product Ideas?,Druid Summer Conference,

2009 , http://www2.druid.dk/conferences/viewpaper.php?id=5682\&cf=32.

[94] Pollitt Ch., Bouckaert G., Public Management Reform: A Comparative Analysis, Oxford University Press, Oxford 2004.

[95] Porta M., House B., Buckley L., Blitz A., Value 2.0: eight new rules for creating and capturing value from innovative technologies, "Strategy\&Leadership" 2008, 36(4).

[96] Powell W., Koput K., Smith-Doerr L., Interorganizational Collaboration and the Locus of Innovation: Networks of Learning in Biotechnology, "Administrative Science Quarterly"1996, 41 (1).

[97] Quinn A. J., Bederson B.B., Human computation: a survey and taxonomy of a growing field, Proceedings of the SIGCHI Conference on Human Factors in Computing Systems, 2011.

[98]Reichwald R., Piller F., Interaktive Wertschöpfung. Open Innovation, Individualisierung und neue Formen der Arbeitsteilung, Wiesbaden, Gabler 2006.

[99] Ribiere V.M., Tuggle F.D., Fostering innovation with KM 2.0, "VINE" 2010, 40(1).

[100] Rouse A.C., A preliminary taxonomy of crowdsourcing, 21st Australasian Conference on Information Systems, 2010.

[101] Rowley J., Slack F., Conducting a literature review, "Management Research News" 2004, 27(6).

[102] Schenk E., Guittard C., Crowdsourcing: What can be Outsourced to the Crowd, and Why?, "HAL: Sciences de l'Homme et de la Société" 2009.

[103] Schwarz J.A., Public Service Broadcasting and Data-Driven Personalization: A View from Sweden, "Television\&New Media"2016, 17(2).

[104] Shah S., Motivation, Governance, and the Viability of Hybrid Forms in Open Source Software Development, "Management Science" 2006, 52(7). 
[105] Shepherd H., Crowdsourcing, "Contexts" 2012,11(10).

[106] Seltzer E., Mahmoudi D., Citizen Participation, Open Innovation, and Crowdsourcing: Challenges and Opportunities for Planning, "Journal of Planning Literature" 2012, 28(1).

[107] Sloane P., A Guide to Open Innovation and Crowdsourcing: Advice from Leading Experts, Kogan Page Publishers,UK 2011.

[108] Sinha R., The silent innovators, "One India, One People" 2008, 15-17.

[109] SolemonB., Ariffin I., Din M. M., Anwar M. R., A review of the uses of crowdsourcing in higher education", International Journal of Asian Social Science" 2013, 3(9).

[110] Stabryła A., Wawak S. (red.), Problemy zarzadzania organizacjami $w$ społeczeństwie informacyjnym, Wydawnictwo Mfiles.pl, Kraków 2014.

[111] Stacey R. D., Strategic Management and Organizational Dynamics,Pitman,London 1993.

[112] Stiver A., Barroca L., Petre M., Richards M., Roberts D., Civic crowdfunding: how do offline communities engage online?,British HCI Proceedings of the 2015 British HCI Conference, 2015.

[113] Suciu Ch. M., Suciu N., Co-creation and innovation-driven business model: linked Open innovation \& crowd sourcing, "International Business Information Management Association" 2012, 1-4.

[114] Surowiecki J., The Wisdom of Crowds: Why the Many Are Smarter Than the Few and How Collective Wisdom Shapes Business, Economies, Societies, and Nations, Doubleday,New York 2004.

[115] Toubia O., Idea Generation, Creativity, Incentives, "Marketing Science" 2006, $25(5)$.

[116] Unterberg B., Crowdsourcing, [In:] Social Media Handbuch: Theorien, Methoden, Modelle, D. Michelis, T. Schildhauer, Nomos Verlag, Baden-Baden 2010.

[117] Wexler M.N., Reconfiguring the sociology of the crowd: exploring crowdsourcing, "International Journal of Sociology and Social Policy" 2011, $31(1 / 2)$.

[118] Wheatley M., Leadership and the New Science: Discovering Order in a Chaotic World, Berrett-Koehler Publishers 1994.

[119] Whitla P., Crowdsourcing and its Application in Marketing Activities, "Contemporary Management Research" 2009, 5(1).

[120] Vukovic M., Crowdsourcing for enterprises, Proceedings of the 2009 Congress on Services - I, IEEE Computer Society, 2009.

[121] Von Hippel E., Democratizing Innovation, MIT Press Cambridge,Massachusetts 2005.

[122] Yang Y., Chen Pei-Tu, Pavlou P., Open Innovation: An Empirical Study of Online Contest, Proceedings of Thirteenth International Conference on Information Systems, Phoenix, 2009. 


\section{CROWDSOURCING IN THE PUBLIC SECTOR - A RESEARCH CHALLENGE}

Crowdsourcing in a general approach signifies a process of acquiring knowledge, ideas, and inspirations from the crowd. In this aspect, the Internet is a supplementary tool and a specific medium. In economic practice it has become a megatrend, which drives innovations, collaboration in the field of scientific research, business, or society. It is reached by more and more organisations, for instance considering its potential business value. One perceives a connection between crowdsourcing and building of a competitive advantage, improving business processes , optimising of the costs of the organisation's activity or business models. This notion of crowdsourcing is gaining more and more interest among researchers. However, according with the opinion of many authors, the majority of publications is oriented at using it in commercial organisations. This phenomenon is insufficiently analysed from the point of view of public organisations. At the same time it is emphasised that crowdsourcing in public organisations is the current direction of research since crowdsourcing is viewed as a combination of collaboration, aggregation, collective work, consensus, and creativity. What is important is that public organisations begin to reach for this type of solution. In this article the idea of crowdsourcing was brought closer, further on a review of existing research studies related to crowdsourcing in public organisations was presented and possible directions of further research were outlined. The main goal of this article is presenting the existing theoretical and empirical output connected with crowdsourcing in public organisations indicating current research challenges in this field. The methodology of a systematic literature review was used in order to realise the goal constructed in this way. Based on that, the following research challenges were proposed: harmonisation and making more specific the notion's conceptualisation, conducting multidimensional and holistic research taking into account the role of the worker and the crowd, developing ways of measuring, and the conceptual framework of organisational conditions.

Keywords: crowdsourcing, public organisations, public sector, systematic literature review, conceptualisation.

DOI:10.7862/rz.2017.hss.10

Przesłano do redakcji: styczeń 2017

Przyjęto do druku: marzec 2017 